\title{
PATHOGENESIS OF ANKYLOSING SPONDYLITIS AND RHEUMATOID ARTHRITIS
}

\author{
Proceedings of the Second International Symposium \\ held at the Middlesex Hospital \\ 14-15 April 1987
}

\section{ORGANIZING INSTITUTIONS}

Department of Rheumatology Research. University College and Middlesex Hospital Medical School. London WI 2PG.

Immunology Unit.

Department of Biochemistry,

King's College,

University of London.

London W8 7AH.
ORGANIZING COMMITTEE

DR. MARY CORBETT

DR. A. EBRINGER

DR. M. SHIPLEY

Dedicated to Dr. D. C. O. James,

Consultant Haematologist at the Westminster Hospital and Medical Director of the Anthony Nolan Laboratories 


\title{
CONTENTS
}

List of Participants

Introduction by Alan Ebringer

Tuesday 14 April 1987

\author{
FIRST SESSION
}

Chairman: Mary Corbett

Morning

1. Perspectives in the Actiology of Seronegative Polyarthritis by $V$. Neumann and $V$. Wrigh

2. Genetics of HLA-B27 by M. A. Khan

3. Molecular Biology of the HLA-B27 Locus by Elisabeth H. Weiss, Kathi Bloemer, Christa Doerner, W. Kuon. Margot Lang. Heike Pohla, M. Schattenkirchner and $G$. Riethmüller

4. HLA-B7/B27 Constructs: a Tool to Understand the Molecular Mimicry Hypothesis between HLA-B27 and Gram-negative Bacterial Antigens in Ankylosing Spondylitis $b y \cdot A$. Toubert, J. Sire, R. Sodover, B. Amor and B. R. Jordan

5. Lymphocyte Response to Enterobacterial Biostructures in Seronegative Spondarthritis: Specific T-cell Mediated Immunity or Non-specific Polyclonal B-cell Activation? by W. L. Gross. C. Lohmann. Gitta Lüdemann and J. Lïdemann

6. Gram-negative Bacteria, HLA-B27 and Inflammatory Bowel Disease by $P$. E. Pease, M. R. Lane, H. Chahal, J. E. Tallack and R. N. Allan

7. Cross-reactivity Studies on Bacteria Believed to be Associated with Inflammatory Bowel Disease (IBD). Ankylosing Spondylitis (AS) and Reactive Arthritis (ReA) by P. E. Pease, H. Chahal, J. E. Tallack, M. R. Lane and R. N. Allan

8. Criteria for Ankylosing Spondylitis: Facts and Fallacies by J. M. H. Moll

9. The Association between Ankylosing Spondylitis, Acute Anterior Uveitis and HLA-B27: the Results of a Swiss Family Study by S. M. van der Linden, H. U. Rentsch. N. Gerber, A. Cats and H. A. Valkenburg

10. Acute Anterior Uveitis and Faecal Carriage of Gram-negative Bacteria by $R$. Ebringer

1

Tuesday 14 April 1987

\section{SECOND SESSION}

Chairman: Michacl Shipley

Aftcrnoon

11. Factors Associated with the Development of Reactive Arthritis by A. Toivanen, R. Termi, R.Lahesmaa-Rantala, T. H. Ståhlberg and K. Granfors

12. Experimental Yersinia-associated Arthritis in the Spontaneously Hypertensive Rat by $P$. Toivanen, R. Merilahii-Palo, C. Gripenberg, K.-O. Söderstrom and U.-M. Jaakkola.

13. Molecular Mimicry: Fact or Fiction? by D. T. Y. Yu

14. Rabbit Antisera to Enterobacteriaceale isolated from HLA-B27 Positive Patients with Ankylosing Spondylitis are Lytic for the Mononuclear Cells of AS Patients by C. $J$. Beukelman, A. van Leeuwen, P. C. Aerts, E. van Kregten, S. van Bree, J. J. van Rood, J. M. N. Willers and H. van Dijk

15. Enterobacterial Involvement in the Pathogenesis of Secondary Ankylosing Spondylitis $b y$ Ch. G. van Bohemen, E. Weterings, H. S. Goei The, F. C. Grumet and H. C. Zamen

16. Expression of HLA Antigens on the Human Uvea by D. Abi-Hanna and D. Wakefield

17. Klebsiella Antibodies in Ankylosing Spondylitis and Proteus Antibodies in Rheumatoid Arthritis by A. Ebringer, N. L. Cox, I. Abuljadayel, M. Ghuloom, S. Khalafpour, T. Ptaszynska, F. Shodjai-Moradi and C. Wilson

18. Antibodies to Klebsiella and Proteus Microorganisms in Ankylosing Spondylitis and Rheumatoid Arthritis Patients Measured by ELISA by $S$. Khalafpour, A. Ebringer, $I$. Abuljadayel and M. Corbett

19. Antibodies to Proteus in Rheumatoid Arthritis by P. Rogers, J. Hassan, B. Bresnihan, C. Feighery and A. Whelan

20. Ileocolonoscopic Findings in Seronegative Spondylarthropathies by H. Mielants, E. M. Veys, C. Cuvelier and M. De Vos

21. Pathogenesis of Ankylosing Spondylitis: the State of the Art by A. Calin 
22. Historical Aspects of the Aetiology of Rheumatoid Arthritis by E. G. L. Bywaters

23. Pathophysiology of Chronic Synovitis by J. C. W. Edwards

24. Is there a Role for Epstein-Barr Virus in the Aetiology of Rheumatoid Arthritis? by P. M. Lydyard and $W$. L. Irving

25. Abnormal Mitochondria in Cultured Synovial Fibroblasts in Rheumatoid and Reactive Arthritis? by E. Eerola, K. Pulkki, L. J. Pelliniemi, E. Vuorio and A. Toivanen

26. HLA-DR4 and Other Genetic Markers in Rheumatoid Arthritis by P. Stastny, E. J. Ball, M. A. Khan, Nancy J. Olsen, T. Pincus and X. Gao

27. Antigens of HLA-DR Locus in Rheumatoid Arthritis by Z. Jajić and I. Jajić

28. Induced Expression of Class II Transplantation Antigens in the Cartilage-Pannus Junction in RA: Chronic Synovitis as a Model System for Aberrant T-lymphocyte Activation by $L$. Klareskog and $O$. Johnell

29. Prevalence of Familial Occurrence in Patients with Rheumatoid Arthritis by $F$. Wolfe. Sue M. Kleinheksel and M. A. Khan

\section{Chairman: J. C. W. Edwards}

30. Pathogenetic Factors in Rheumatoid Synovitis by M. Ziff, D. Cavender and D. Haskard

31. Rheumatoid Factor: Structural and Genetic Studies indicating Novel Binding Sites may confer the Specificity for IgG Fc by F. C. Hay

32. Rheumatoid Arthritis as a Glycosylation Disorder by R. B. Parekh, R. A. Dwek and T. W. Rademacher

33. Decreased B-cell Galactosyltransferase activity in Rheumatoid Arthritis by J. S. Axford

34. The Middlesex Hospital Prospective Study of Early Rheumatoid Disease by Mary Corbett and A. Young

35. Observations on the Causes of Rheumatoid Arthritis by $S$. Atkin, D. Walker, M. Mander, A. Malcolm and W. Carson Dick

36. An Overview of Research into Ankylosing Spondylitis and Rheumatoid Arthritis by R. N. Maini 


\section{MOLECULAR BIOLOGY OF THE HLA-B27 LOCUS \\ BY ELISABETH H. WEISS, KATHI BLOEMER, CHRISTA DOERNER, W. KUON, MARGOT LANG, HEIKE POHLA, M. SCHATTENKIRCHNER AND G. RIETHMÜLLER}

Correspondence to Dr. Weiss.

\section{SUMMARY}

The molecular biology of the HLA-B27 locus is reviewed. The HLA-B27 gene itself does not differ between healthy individuals and ankylosing spondylitis patients. Several unique features of the HLA-B27 molecule have been identified and one epitope was proposed to cross-react with bacterial proteins.

KFY wORDS: DNA, Intron probe, Polymorphisms, Cosmid clones.

THE human major histocompatibility complex (MHC) or HLA complex (human leucocyte antigen) located on the short arm of chromosome 6 contains at least 17 closely linked genes, which code for the heavy chains of the class I antigens. These glycosylated polypeptides are expressed on the ccll surface associated with $\beta_{2}$-microglobulin. The gene products of the highly polymorphic loci, HLA-A, HLA$B$, and HLA-C are transplantation antigens which have been shown to serve as recognition and restriction elements for cytotoxic T-lymphocytes. Because of the importance of these antigens in clinical transplantation, the genetic polymorphism of the HLA complex has been extensively studied. The finding that HLA antigens are associated with disease susceptibility was rather unexpected. The most remarkable association is that of the HLA-B27 allele and ankylosing spondylitis (AS) with a relative risk of 69 [1-3]. Although the strength of the association of the HLA-B27 antigen and AS renders the HLA-B27 gene unique among the class I gene family, the HLA-B27 gene was only recently isolated. Several groups have cloned HLA-B27 gene sequences (see Table I) [4-7] and the amino acid sequences of four HLA-B27 subtypes have also been obtained by protein sequencing [ $8-$ $11]$. The gene organization has been determined by isolating cDNA and genomic cosmid clones $[4,5]$ from gene libraries constructed of DNA prepared from peripheral white blood cells (PBL) and of RNA isolated from a homozygous B-cell line (B LCL) of persons with no history of disease. Seemann et al. [6] reported two HLA-B27 subtype sequences cloned from a B-cell line (HLA-B27.1/27.2) which differ only by four nucleotides resulting in three amino acid exchanges. All HLA-B27 sequences are identical in the protein coding regions, the differences found in the LG2-cDNA sequence being due to cDNA cloning artefacts. It is not known whether the several nucleotide differences detected in the intron sequences are due to a low genetic variability of intron sequences or might be explained by sequencing errors.

Although previous studies did not give any indication that the HLA-B27 molecule of AS patients might differ from the antigen of healthy individuals, the possibility still remained of a pathogenic HLA-B27 variant present in affected individuals which has not so far been detected at the protein level. We therefore isolated HLA-B27 specific cDNA clones from a cDNA library constructed with

TABLE I

TABle of HLA-B27 Sequences

\begin{tabular}{|c|c|c|c|c|c|c|c|c|}
\hline \multirow{4}{*}{$\begin{array}{l}\text { CD } \\
\text { LG2 } \\
\text { BRUG }\end{array}$} & \multirow{4}{*}{$\begin{array}{l}\text { Library } \\
\text { genomic } \\
\text { cDNA } \\
\text { genomic }\end{array}$} & \multicolumn{2}{|l|}{ Source } & \multicolumn{2}{|c|}{ HLA haplotype } & \multirow{4}{*}{$\begin{array}{l}\text { DNA sequence } \\
\text { complete gene } \\
\text { coding } \\
\text { complete gene } \\
\text { gap in intron } 3\end{array}$} & \multirow{2}{*}{$\frac{\text { AS }}{-f}$} & \multirow{2}{*}{$\frac{\text { Publication }}{\text { Weiss et al. }[4]}$} \\
\hline & & PBL & A2, & $\mathrm{B} 27 / 51$, & $\mathrm{Cw} 2 / 4$ & & & \\
\hline & & B LCL & A 2 , & B27, & Cwl & & $-m$ & Szoets et al. $[5]$ \\
\hline & & B LCL & A $3 / 11$ & B27.1/2 & $\mathrm{Cw} 1 / 2$ & & & Seemann et al.[6] \\
\hline $\mathrm{KCA}$ & genomic & B LCL & A11/w24, & B27/w44. & $\mathrm{Cw} 1 / 5$ & $\operatorname{exon} 2-4$ & $-m$ & $\begin{array}{l}\text { Coppin \& } \\
\text { McDevitt[7] }\end{array}$ \\
\hline MRWC & genomic & B LCL & $\mathrm{A} 2 / 32$ & B14/27, & $\mathrm{Cw} 2$ & $\operatorname{exon} 2-4$ & + & $\begin{array}{l}\text { Coppin \& } \\
\text { McDevitt[7] }\end{array}$ \\
\hline MVL & genomic & $\mathrm{B} \mathrm{LCL}$ & Aw32, & B27, & Cw2 & $\operatorname{exon} 2-4$ & - & $\begin{array}{l}\text { Coppin \& } \\
\text { McDevitt[7] }\end{array}$ \\
\hline
\end{tabular}

Correspondence to Dr. Weiss. 
DNA from PBL of an AS patient (HLA-A2/23, B27/w60, Cw2/3) and Coppin and McDevitt [7] clon:d the genomic sequence using a B-cell line established from an affected individual. The DNA sequence data, derived from the protein coding and the 3 'untranslated region, demonstrate that the HLA-B27 gene is identical in healthy persons and AS patients.

The genomic organization of the HLA-B27 gene, that is the excon/intron structure, is similar to that of other human class I genes (Fig.1.). The overall homology, between the HLA-B27 gene and other HLA-B alleles, e.g. HLA-B7, is the same as is observed when comparing two HLA-A alleles. A h gh degree of sequence divergence is found outside of the gene itself, in the 3' flanking region, wher the HLA-B27 is compared to HLA-B7 [12] or HLA-B51 [13], alleles for which DNA sequence data in this region are available. The genomic sequence of the HLA-B27 gene does not provide an obvisus explanation for the disease association of this HLA-B allele.

HLA-B 27.1

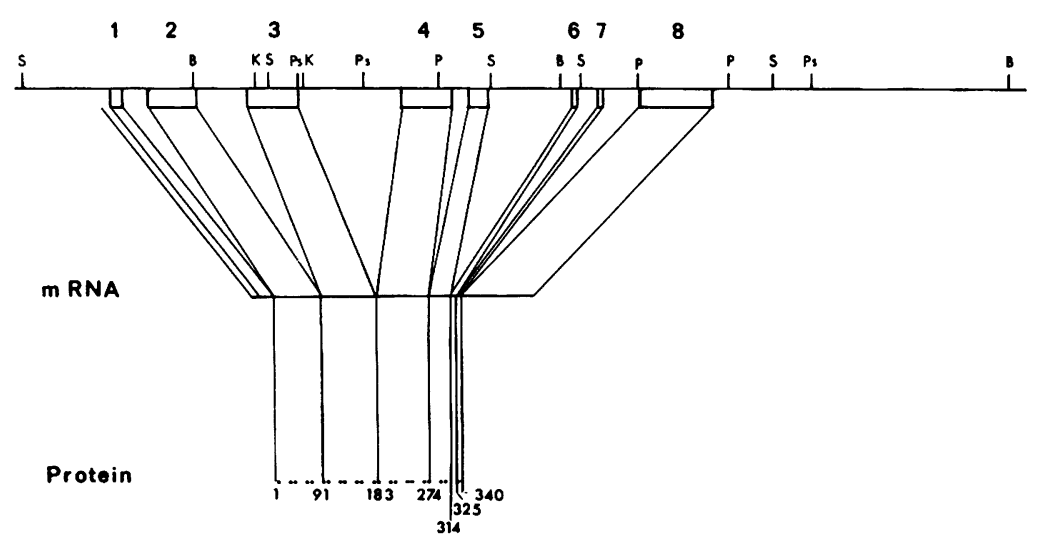

Fici. 1. - Structure of the HLA-B27. 1 locus.

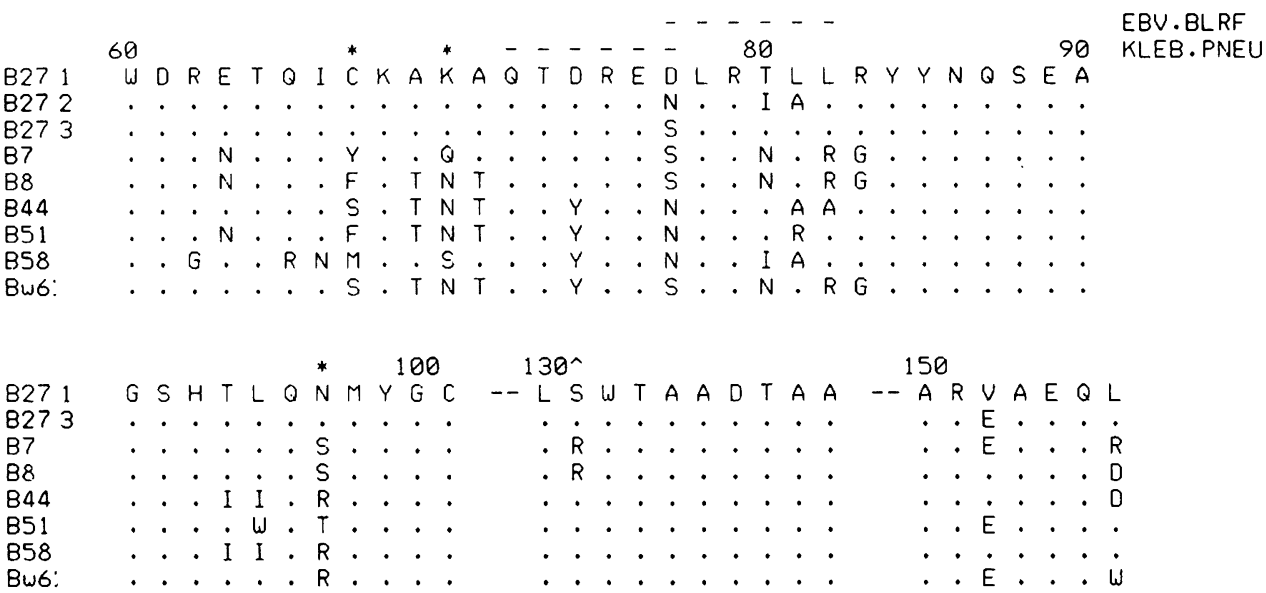

FIci. 2. - Comparison of HLA-B27 sequences with other HLA-B antigens. 
The protein nature of the HLA-B27 molecule is similar to other class I antigens, as the polymorphic amino acid substitutions are found in the polymorphic segments of the class I heavy chain (Fig. 2). Three amino acid residues (aa) are present which are unique to the HLA-B27 antigen and its subtypes, and are not found in any other HLA molecule sequenced so far. Two of these changes can be valued as unremarkable as they represent conservative substitutions: lysine (K) in ai position 7() and asparagine $(\mathrm{N})$ in 97 . Other HLA antigens also contain a basic amino acid residue in these positions. These conservative substitutions are unlikely to influence the structure or biological activity of the molecule in a unique fashion. One replacement. however, seems unusual: position 67 is occupied by a potentially reactive cysteine residuc $(C)$ that might influence the intermolecular interactions of HLA-B27, due to its location in an area that is probably exposed on the surface of the membrane molecule. We are currently using site directed mutagenesis to investigate what influenee the HLA-B27 unique amino acid substitutions have on the structure of the molecule as detected by serological reagents or by allospecific cytotoxic T-lymphocytes. The structural unicpueness of HLAB27 which might be responsible for its discase association. may be created by several contiguous amino acid residues in the polymorphic regions. On the other hand it also might be a unique conformational epitope of the HLA-B27 molecule. It can be postulated that the HLA-B27 unique substitutions conserved among the subtypes might be involved in the major antigenic determinants of HLA-B27 and might serve as a molecular site of correlation with the disease.

Oldstone et al. [14] have described a linear sequence of six amino acids present both in HLAB27.1 and in Klebsiella pneumoniae (Fig. 2) which, they propose, represents the epitope responsible for the cross-reactivity of HLA-B27 and Klebsiella, first described by Ebringer [15]. As no single HLA-B27 subtype shows a preferential correlation with AS, the putative cross-reactive epitope should be common to all HLA-B27 variants. Only five amino acids of the Klebsiella sequence are conserved in HLA-B27.2 and HLA-B27.3. The HLA-B27.3 subtype sequence in this region is identical to the sequence present in the HLA-B7 [12] and the HLA-B8 [16] antigen. It therefore remains to be studied if the proposed amino acid sequence of Klebsiella pneumoniae is responsible for the cross-reactivity observed between HLA-B27 and certain microbial agents, and therefore the induction of AS through molecular mimicry.

Initially it was suggested that there might be another disease susceptibility gene for AS in strong linkage disequilibrium with the HLA-B27 locus (the 'two gene theory'). As it has not been possible to prove unequivocally that the HLA-B27 gene or its product is directly involved in disease pathogenesis ('one gene theory') attempts were made to identify a second polymorphic gene in the HLA-B27 subregion. Several groups used class I specific probes to analyse the configuration of the HLA-B27 gene by genomic Southern blot analyses in order to identify HLA-B27 specific restriction fragment length polymorphisms (RFLP) which might indicate a unique genetic arrangement at the HLA-B27 locus or detect a polymorphism varying in the presence of AS. Using a class I cDNA probe Trapani et al. described a polymorphic $3.5 \mathrm{~kb}$ (kilobases) TaqI fragment specific for genomic DNA of HLA-B27 positive individuals [17]. This fragment is present irrespective of the disease status. Ness and Grumet [18] searched for HLA-B27 specific polymorphisms employing an intragenic probe, derived from intron 7 of the HLA-B7 gene on TaqI digested genomic DNA. The TaqI restriction enzyme is preferentially used in RFLP studies, as it recognizes a four base pair sequence, thus cleaving quite frequently, which contains a $\mathrm{CpG}$ in its recognition sequence. The $\mathrm{C}$ in $\mathrm{CpG}$ dinucleotides can be methylated and is thus prone to mutations. Using the intron probe four polymorphic TaqI restriction fragments of $2.5,3.4,3.8$ and 4.0 or $8.0 \mathrm{~kb}$ were detected for HLA-B27. The most common fragment among Caucasians is the $3.4 \mathrm{~kb}$ band, as first described by Trapani et al. [17]. The $3.8 \mathrm{~kb}$ band has been found in one individual and the $4.0 / 8.0 \mathrm{~kb}$ fragment in three unrelated individuals. The $2.5 \mathrm{~kb}$ TaqI fragment which is characteristic for the HLA-B7 gene [12], can also be detected in a few HLAB27 positive normal Caucasians but almost never appears in AS patients, suggesting a trend that is not yet statistically significant. Reveille et al. reported on a $9.2 \mathrm{~kb}$ Pvull fragment which is present in HLA-B27 positive AS patients and less frequently found in HLA-B27 positive healthy individuals $[19,20]$. The presence of both HLA-B27 and the $9.2 \mathrm{~kb}$ PvulI RFLP in an individual conferred a relative risk for AS of 297, compared to 119 with HLA-B27 alone. This polymorphism which can also be found in non-HLA-B27 haplotypes, was detected using either a full length HLA-B cDNA probe or the shorter HLA-B locus specific fragment, encoding the 3' untranslated region of the HLA-B mRNA. We tested a large panel of HLA-typed unrelated healthy individuals, AS patients and three families with at least one AS patient using the HLA-B27 full length cDNA clone pB1 [5] and the 3' PstI fragment of $\mathrm{pBl}$ as a HLA-B locus specific probe on genomic Southern blot analyses. The majority of the approximately 50 individuals investigated so far possess the $9.2 \mathrm{~kb}$ PvuII fragment 


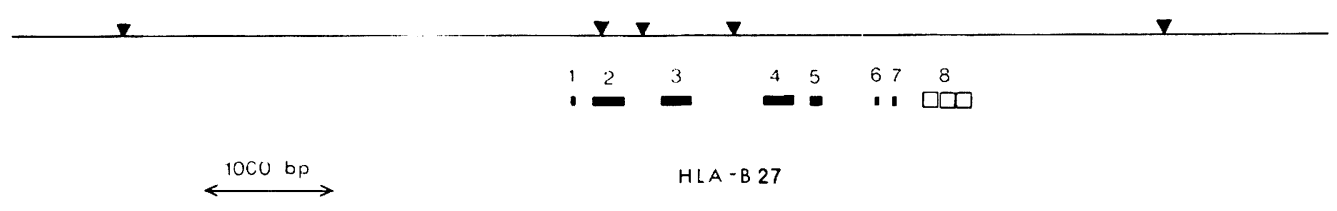

FIGi. 3. - Taql restriction map of HLA-B27 locus.

described by Revcille et al. The discrepancies between the two studies may be explained by the fact that two different populations were tested. The $9.2 \mathrm{~kb}$ Pvull fragment is not derived from the $3^{\prime}$ end of the HLA-B27 gene, as this region is contained on a 540 bp (base pair) PvuII fragment characteristic for all HLA-B alleles tested so far.

Steere et al. [21] used two adjacent DNA probes derived from the 5' flanking region of the HLA$B$ locus just upstream of the HLA-B7 gene which cross-hybridize with the HLA-C gene. They identified a $4.0 \mathrm{~kb}$ TaqI fragment specific for the HLA-B27 gene in AS patients and controls. These results and the intragenic Taql cleavage sites derived from the HLA-B27 gene sequence [4] allowed us to construct a TaqI restriction map of the HLA-B27 locus as shown in Fig. 3.

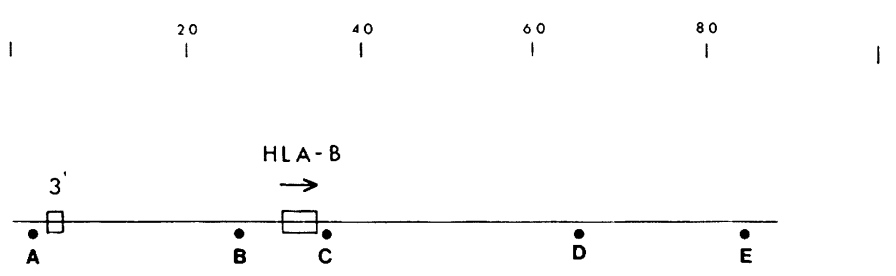

FIci. 4. - Schematic presentation of the HLA-B subregion. The position of the HLA-B gene and the $3^{\prime}$ class I half gene are shown as boxes. The orientation of the HLA-B gene $5^{\prime}$ to $3^{\prime}$ is indicated by the arrow. The scale above the cloned DNA scgment is given in kilobases $(k b)$. The origins of the probes used for genomic Southern blot analyses are shown. (A) $5.0 \mathrm{~kb} \mathrm{KpnI/HindIII} \mathrm{fragment;} \mathrm{(B)} 800 \mathrm{bp} \mathrm{Sall} /$ Xhol fragment of CD2.6 [4]; (C) $2.3 \mathrm{~kb}$ Pstl/EcoRI fragment of the $6.8 \mathrm{~kb}$ HLA-B27. I EcoRI subclone: (D) $1.15 \mathrm{~kb}$ Taq I fragment: (E) $800 \mathrm{bp}$ Pstl/Xhol fragment.

We extended the cloned DNA of the HLA-B locus isolated in the cosmid CD2.6 containing the HLA-B27.1 gene, by chromosomal walking experiments and have characterized $90 \mathrm{~kb}$ of this region (Fig. 4). A $3^{\prime}$ half gene is localized on a $1.6 \mathrm{~kb}$ HindIII fragment $5^{\prime}$ to the HLA-B gene which can be detected in all haplotypes studied so far. Several fragments were derived from the HLA-B subregion which can serve as single or low copy probes. The restriction fragments used in further analyses as HLA-B region probes are shown in Fig. 4. We searched for polymorphisms either specific for the HLA-B27 gene or specific for AS patients. Examples of genomic restriction enzyme digests hybridized with the various probes are shown in Fig. 5. The probes B, D and E did not detect any polymorphic restriction sites in this region. The fragment B cross-hybridized with four additional bands in the genomic DNA and probe $E$ with one. Polymorphic variation was observed at the very $5^{\prime}$ end of the cloned HLA-B subregion with probe A and in the HLA-B $3^{\prime}$ flanking region with fragment C. The HLA-B27 3' flanking probe was particularly promising because it detects polymorphic restriction sites with almost every enzyme tested, e.g. BglII, HindIII, PvuII, Rsa, and TaqI. This large number of observed RFLPs in the HLA-B 3' flanking region was not totally unexpected as a high level of divergence was observed at the DNA sequence level. The reason for this great sequence divergence in the HLA-B 3' flanking region is not known. No additional RFLP besides the known 3.5 $\mathrm{kb}$ TaqI polymorphism $[17,18]$ was observed with the seven restriction enzymes tested which segregated with the HLA-B27 allele. In addition, none of the polymorphic restriction sites correlated with the disease status. Further experiments are needed to study this highly polymorphic DNA segment in more detail. 
FAMILYS.

a

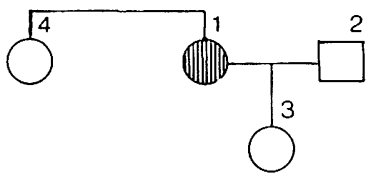

$27 \quad 27$

AS

$\begin{array}{llll}k b & 4 & 3 & 2\end{array}$

$4321 k b$

6.5
1

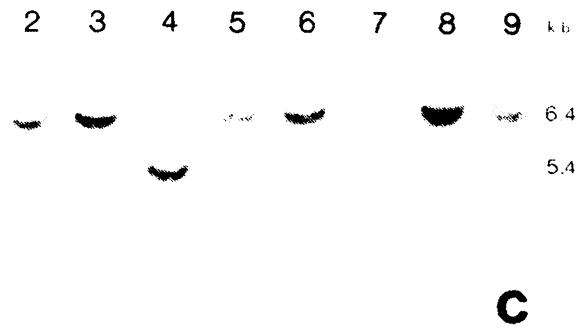

$k b$ B) MJ LG2BJ MJ kb

9.8 $k b$

b

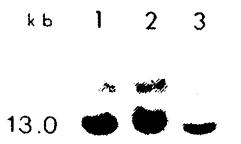

Fici. 5. - Genomic Southern blot analyses hybridized with the various probes. (a) Family S., autoradiographs of Southern blots: (b) of Sacl (left) and PstI (right) digested genomic DNA isolated of family S., hybridized with probe $\mathrm{A}$ : (c) of $\mathrm{BamHI}$ digested genomic DNA from family $S$. hybridized with probe $\mathrm{B}$ : (d) of BgilI $4.9-$ digested genomic DNA of HLA-B27 positive (HLA-B27/27 in lane 4 and HLA-B13/27 in lane 9) and HLA-B27 negative individuals, hybridized with probe C; (e) of Pvull (left) and TaqI (right) digested genomic DNA of cell lines BJ (HLA-B7/8), MJ (HLA-B8). and LG2 (HLA-B27/27), hybridized with probe D; (f) of Sacl (left) and PstI C B (right) digested genomic DNA of family S., hybridized with probe $E$.
1.25

1.15

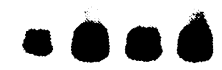

$\begin{array}{lllllllll}4 & 3 & 2 & 1 & 4 & 3 & 2 & 1 & k b\end{array}$
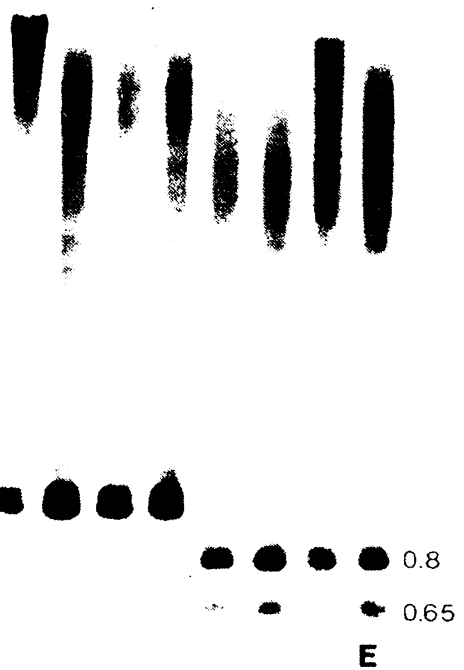
The tumour necrosis factor (TNF) genes $\alpha$ and $\beta$ (lymphotoxin) have recently been localized in the MHC to a region encompassing the complement factor genes and the HLA-B locus [22]. These polypeptide hormones are potent pleiotropins with a wide range of bioactivities and a major importance to the pathogenesis of inflammatory responses. As the TNF genes might constitute the hypothetical gene $\mathrm{X}$, the disease susceptibility gene for AS in strong linkage disequilibrium with the HLA-B27 gene, we isolated the human TNF locus in overlapping cosmid clones. In preliminary experiments we used a human TNF- $\alpha$ probe to investigate the locus in HLA-B27 positive and negative individuals and in AS patients. No difference was found for the three groups tested.

\section{CONCLUSIONS}

In summary, several hypotheses have been proposed to explain the association of the HLA-B27 allele with spondylarthropathies. The isolation and expression of the gene encoding the HLA-B27 antigen allows investigation of the proposed mechanisms at the single gene level independent of the human genetic background. The HLA-B27 gene itself does not differ between healthy individuals and AS patients. Several unique features of the HLA-B27 molecule have been identified and one epitope was proposed to cross-react with bacterial proteins. The isolated gene will be helpful in a study of the possible receptor function of this class I molecule and for an investigation of the molecular mimicry hypothesis. In an attempt to understand the AS-HLA-B27 association the extended HLA-B region and the TNF genes have also been extensively investigated. Polymorphic restriction sites in this region associated with HLA-B27 and the presence of AS could indicate a disease susceptibility gene linked to HLA-B27. The DNA located $5^{\prime}$ and $3^{\prime}$ of the HLA-B gene is polymorphic. However, no RFLP was found to be significantly increased in frequency in HLA-B27 positive AS patients compared to the HLA-B27 positive control group. The failure to detect polymorphisms which correlate with ankylosing spondylitis might suggest that genes important in the development of AS are not present in these regions.

\section{ACKNOWLEDGEMENTS}

This work was supported by the Genzentrum, Munich and by a grant of the Deutsche Forschungsgemeinschaft (SFB 217).

\section{RIFERENCTS}

1. Schlosstein L. Terasaki PI, Bluestone R. Pearson CM. High association of an HL-A antigen, W27, with ankylosing spondylitis. $N$ Engl J Med 1973:288:704-6.

2. Brewerton DA. Caffey M, Hart FD. James DCO. Nicholls A. Sturrock RD. Ankylosing spondylitis and HLA 27. Lancet 1973:i:9(1)4-7.

3. Tiwari $\mathrm{JL}$. Terasaki PI. Ankylosing spondylitis. In HLA and disease associations. Heidelberg: Springer Verlag. 1985:85-100.

4. Weiss EH, Kuon W, Doerner C, Lang M. Riethmueller G. Organization. sequence and expression of the HLA-B27 gene: a molecular approach 10 analyze HLA and disease associations. lmmunobiology $1985: 170: 367-8()$.

5. Szoets H. Riethmueller G. Weiss EH. Meo T. Complete sequence of HLA-B27 cDNA identified through the characterization of stuctural markers unique to the HLA-A. -B. and -C allelic series. Proc Narl Acad Sci USA 1986:83:1428-32.

6. Seemann GHA. Rein RS, Brown CS. Ploegh HL. Gene conversion-like mechanisms may generate polymorphism in human class 1 genes. EMBO J 1986;5:547-52.

7. Coppin HL. McDevitt, HO. Absence of polymorphism between HLA-B27 genomic exon sequences isolated from normal donors and ankylosing spondylitis patients. J Immunol 1986:137:2168-72.

8. Ezquerra A. Bragado R, Vega MA. Strominger JL. Woody JN, Lopez de Castro JA. Primary structure of papain-solubilized human histocompatibility antigen HLA-B27. Biochemistry 1985:24:1733-41.

9. Vega MA. Wallace L. Rojo S. Bragado R. Aparicio P. Lopez de Castro JA. Delineation of functional sites in HLA-B27 antigens. Molecular analysis of HLA-B27 variant Wewak I defined by cytolytic T lymphocytes. $J$ lmmunol 1985:135:3323-32.

10. Vega MA. Ezquerra A, Rojo S, Aparicio P. Bragado R. Lopez de Castro JA. Structural analysis of an HLAB27 functional variant: identification of residues that contribute to the specificity of recognition by cylolytic T lymphocytes. Proc Nat Acad Sci USA 1985:82:7394-8.

11. Vega MA. Bragado R. Ivanyi P. Pelaez JL. Lopez de Castro JA. Molecular analysis of a funçtional subtype of HLA-B27: a possible evolutionary pathway for HLA-B27 polymorphism. J Immunol 1986:137:3557-65.

12. Biro PA. Pan J, Sood AK. Kole R, Reddy VB, Weissman SM. Sequences of human repetitive DNA, nonglobulin genes, and major histocompatibility locus genes. III. The major histocompatibility complex. Cold 
Spring Harbor Symp Quam Biol 1983:47:1079-86. (An updated sequence was kindly provided by P.A. Biro.)

13. Weiss EH. Unpublished results.

14. Oldstone MB, Schwimmbeck P. Dyrberg T, Fujinami R. Mimicry by virus of host molecules: implications for autoimmune disease. In: Progress of Immunology VI. New York: Academic Press. Inc. 1986:787-95.

15. Ebringer A. Cowling P. Ngwa-Suh N, James DCO. Ebringer RW. Crossrealctivity between Klebsiella aerogenes species and B27 lymphocyte antigens. In: Dausset J, Svejgalard A. eds. Hi.A and dise'ase'. Paris: INSERM, 1976:58:27.

16. Pohla H, Weiss EH. Manuscript in preparation.

17. Trapani JA. Mickelson CA. McKenzie IFC. A 3.5 kilobase Taql restriction fragment of genomic DNA segregates with HLA-B27. Immunogenetics 1985;24:189-92.

18. Ness DB. Grumet FC. New polymorphisms of HLA-B27 and other B locus antigens detected by RFLP using a locus-specific probe. Humain Immunol 1987:18:65-73.

19. Reveille JD. McDaniel DO. Barger BO. Koopman WJ. Acton RT. Restriction fragment length polymorphism (RFLP) in ankylosing spondylitis (AS): association with a $9.2 \mathrm{~kb}$ Pvull fragment. Arthritis Rherum 1986:29:S26.

20. Reveille JD. McDaniel DO, Barger BO. Koopman WJ. Acton RT. Restriction fragment length polymorphism (RFLP) in the seronegative spondyloarthropathies (SNSA). Arthritis Rhetm 1986:29:S32

21. Steere K. Sidwell B, Leach R. Ward FE. Taurog JD. Orr HT. Use of DNA probes from the 5 flanking region of the HLA-B gene to examine polymorphism at the HLA-B locus. Human Immunol 1986:16:137-17.

22. Spies T. Morton CC. Nedospasov SA. Fiers W. Pious D. Strominger JL. Genes for the tumor necrosis factors $\alpha$ and $\beta$ are linked to the human major histocompatibility complex. Proc Nal Acad Sci USA 1986:83:8699702 .

23. Kottmann AH. Seemann GHA. Guessow HD. Roos MH. DNA sequence of the coding region of the HLAB44 gene. Immunogenerics 1986:23:396-400.

24. Ways JP. Coppin HL. Parham P. The complete primary structure of HLA-Bw58. J Biol Chem $1985: 260: 11924-33$.

\section{DISCUSSION}

$Y u$ : The fragments you are using as probes are perhaps only parts of the genes responsible for the disease susceptibility. The conditions used for hybridization may vary in different centres, which could explain the discrepancies.

Did you use the same conditions, as the other groups, which have found a difference between AS patients and healthy controls?

Weiss: We used the same conditions and we exchanged DNA probes, so they could conlirm our data. Their pattern was identical to ours.

Panayi: You have looked at the structure of the region of the B27 gene. Is there any possibility that regulatory genes could be present in this region and explain the difference between AS patients and healthy controls?

For example, do we know if up-regulation of class I antigens on B27 cells from AS patients or controls occurs differently following stimulation with interferon or 'tumour necrosis factor" (TNF)?

Weiss: We compared the B27 expression with TNF- $\alpha$ and TNF- $\beta$ expression by Northern blot analysis between AS patients and healthy individuals, and we did not find any difference.

However, we did not stimulate the cells to see if there was any differential expression, but these experiments are now in progress.

Williams: You showed some sequence data where there was homology with B27.1, but not with B27.2 and B27.3. Could this homology be due to chance?

Weiss: I do a lot of comparisons and always find homologies, both in human and mouse sytems. So I am not sure, that just because one finds a homology, it has to mean something. In the case of the short peptide sequence, if you propose that the six amino acids fragment is the cross-reactive cpitope. that can't be the case, because the HLA-B27 subtypes share a sequence which consists of five amino acids. Furthermore this same five amino acids sequence is also found in other HLA-B antigens such as $\mathrm{B} 7$ and $\mathrm{B} 8$. 